PEDAGOGISK FORSKNING I SVERIGE Vol. 26 No. 2-3 (2021) ISSN 1401-6788

\title{
Debatt
}

\section{Efterlysning: Disciplinär pedagogik för vetenskaplig autonomi}

\author{
Christer Fritzell \\ Professor i pedagogik, numera pensionerad \\ Email: chfritzell@gmail.com
}

Detta är inte en vetenskaplig artikel där jag redovisar hur en lång rad kloka personer uppfattat pedagogikens mångfaldiga aspekter enligt en omfattande referenslista. Inte heller är det en essä i vilken jag funderar kring någon aspekt av pedagogikens spännande komplikationer. I stället är det ett debattinlägg i vilket jag gör kritiska påståenden utan självklara belägg, exemplifierar utifrån egna erfarenheter, ifrågasätter pedagogikämnets nutida status och föreslår ett programmatiskt utkast till en ljusare framtid.

Men för att motivera beteckningen debatt krävs ju mer än enstaka betraktelser, nämligen utbyte av tankar och mening. Därför är det följande ett försök att stimulera, och måhända provocera, till fortsatt meningsutbyte där andra påvisar hur ensidigt jag resonerar och klargör hur man i stället kan se på saken, allt till gagn för vårt ämne pedagogik.

Uttrycket "disciplinär pedagogik" i rubriken kan framstå som något av en tautologi genom att disciplinbegreppet redan har en latent pedagogisk innebörd. Rotordet från latinets discere kan stå för lärande, och vi känner ju det svenska "discipel" för elev. Historiskt har disciplinering betecknat sätt att ordna kunskap i utbildningssyfte, att strukturera ett stoff för undervisning och lärande. Jag kommer att beröra hur man i både utbildning och forskning kan omsätta själva pedagogikämnet disciplinärt.

Med tanke på alla konnotationer à la Caligula vore det förvisso tacknämligt att slippa använda just ordet "disciplin", men jag hittar inget adekvat alternativ. "Territorium", "kunskapsområde" och liknande duger inte för vad 
jag är ute efter, nämligen att ladda begreppet med en normativ halt av vetenskaplig autonomi, vilket jag ser som centralt för både den interna kunskapsbildningen och ämnets ställning i samhällsdebatten.

Kritik är för kunskap som debatt är för demokrati - sine qua non. Men medan demokratisk debatt har syftet, om än inte alltid konsekvensen, att nå klargöranden inför legitim fördelning av makt, har väl vetenskaplig kritik snarare uppgiften att undanröja maktburen debatt. Till den änden krävs dock att osaklig eller otillräcklig vetenskapsdebatt får ge utrymme för vad som också visar sig ligga i demokratins intresse.

Situationen för pedagogikforskningen tycks idag smått paradoxal. Sällan har väl dess konventionella avgränsning till "3U: utbildning, undervisning och uppfostran" överlappats bättre av brett samhälleligt engagemang än i den nutida offentliga debatten. Samtidigt, i en annan del av det kollektiva medvetandet, verkar pedagogikforskningen mer eller mindre irrelevant för utvecklingen på dessa centrala samhällsområden.

Att skoldebatten i nationell massmedia länge förts av ideologiskt strävsamma kändisakademiker, svassande journalister och hukande politiker i stort utan mothugg från professionellt verksamma pedagoger är en närmast surrealistisk upplevelse. $\AA$ ena sidan tycks ämnets företrädare ibland rent ostentativt exkluderas från nyhetsinslag och reportage, medan det å andra sidan tycks blivit något av en särskild genre att demonstrativt svartmåla ämnet, och ingalunda bara i skrymslen på sociala medier.

Samtidigt är det slående hur klagomålen mot "pedagogik" framförts mot bakgrund av en sällsamt okvalificerad skoldebatt kännetecknad av trivial faktafixering och banala förmedlingsidéer. Med hemmasnickrade "förklaringar" kring selektiva faktaurval framställs egna särintressen som lösningar på djupgående problem. Vore inte situationen i skolväsendet så allvarlig - långt bortom Pisa - kunde man ironisera över dessa historielösa och tidsbundet ytliga propåer som just därför kan göra sig breda. De funktionella samband som här tycks föreligga är snarare i stort behov av kritisk pedagogisk granskning.

Långvariga tendenser inom skola och lärarutbildning tillsammans med det egenartade drevet mot pedagogikforskningen utgör enligt min mening starka motiv för intensifierad intern debatt om tillståndet $i$ ämnet. För egen del anser jag att disciplinfrågan då åter behöver aktualiseras på djupet, inte minst just mot bakgrund av att den externa debatten i stort förs helt vid sidan om fackpedagogikens självständiga analyser och argumenterade ståndpunkter. Ett av akademins äldsta och rimligen mest betydelsefulla samhällsvetenskapliga ämnen förnedras som undermåligt och ointressant. Hur är detta möjligt? 


\section{DEN FRÅNVARANDE ÄMNESDEBATTEN}

För jämnt tio år sedan hade jag en debattartikel under rubriken Pedagogikens kris i denna tidskrift $(\mathrm{Nr} 3$, 2011). Huvudtemat gällde även då ämnets dåliga renommé i offentligheten, och jag hävdade att detta kunde knytas till bristande disciplinär status, både internt och externt. Jag hade förhoppningar om att situationen för pedagogikforskningen trots allt skulle förbättras, särskilt med tanke på den starka tillväxten av antalet disputerade och professorer på området.

Pedagogikens svaga anseende uppmärksammades vid professorsmötet året därpå, och man rapporterade att tilltron till ämnet och dess företrädare tyvärr var svagt och att det egna ansvaret för att synas utåt behövde stärkas. Vad som blev av denna klarsyn kan jag inte bedöma.

Att ämnesföreträdarna var osynliga utåt blev knappast bättre av att debatten inåt tycktes lika lam. Jag avslutade mitt debattinlägg med några uppfordrande frågor om vad detta ämne pedagogik mer principiellt handlar om och egentligen har för uppgifter, i en förväntan om klargörande kritik av min svagsyn i fortsatt debatt. Därav blev absolut ingenting!

Några kollegor hörde av sig privat, men inte en enda uppföljning $i$ tidskriften. Sammantaget fick jag veta noll och intet om hur min som jag trodde delvis provocerande kritik togs emot. Mer väsentligt, inte heller andra läsare fick ta del av några öppna synpunkter på hur olika företrädare såg på tillståndet inom ämnet. Kanske var mina resonemang alltför triviala eller inopportuna för ärade kollegor, mitt inlägg tycktes ha fallit som en sten utan minsta ring på ytan.

Om än luttrad blev det givetvis en besvikelse att jag så illa förmått framföra mina ståndpunkter att ingen bevärdigade mitt försök till debatt minsta lilla bemötande. Att jag nu gör ett nytt försök tyder kanske på överdriven tilltro till de egna argumentens bärkraft, eventuellt bara ett försök i backspegeln till meningssökande $\mathrm{i}$ ett yrkesliv med pedagogik. Oavsett vilket kan jag beträffande den nämnda totala bristen på gehör trösta mig med att även dåvarande redaktören Björn Hasselgren fann den obefintliga debattlusten märklig.

I en särskild reflektion i påföljande nummer konstaterade han att på "den klara och väl genomarbetade debattartikeln 'Pedagogikens kris '... vilken tar upp ett antal centrala frågeställningar pedagogiken som vetenskaplig disciplin just nu ställs inför har inte någon forskande kollega eller annan reagerat, varken skriftligt eller muntligt" (Nr 4, 2011, s. 305). Man kunde annars förmodat att särskilt de som inte delade redaktörens värdering av mitt inlägg kunde ha reagerat, men icke.

Efter att ha poängterat att tidskriften faktiskt startades också just med syftet att befrämja debatt om ämnet, presenterade Hasselgren i nämnda artikel en sammanställning som med pinsam tydlighet påvisade den rudimentära debatten. Det handlade över tid om en handfull inlägg av ett fătal personer, 
och bara undantagsvis något om pedagogikämnet som helhet. Detta alltså i ämnets främsta nationella forum, vilket i sig kunde ha motiverat en djupare analys vilket tyvärr inte kom till stånd.

Jag har nu själv ögnat igenom årgångarna decenniet efter Hasselgrens genomgång och konstaterat att situationen är likartad. I några nummer finns förvisso enskilda debattinlägg, men sämre beställt är det med fortsatt meningsutbyte. Bidragen gäller speciella forskningsuppgifter, men inte $i$ något enda fall hittar jag debattinlägg om pedagogikens samlade problematik eller dess utvecklingsmöjligheter som sammanhållen vetenskaplig disciplin! En mindre luttrad kan stå perplex inför detta faktum. Måhända är externa publikationer och inlägg på sociala medier mer attraktiva som arenor, men de kan rimligen inte fungera som forum för principiell ämnesdebatt.

I ett särskilt nummer av tidskriften häromåret ( $\mathrm{Nr} 5$, 2018) inbjöds ett antal väletablerade professorer att delge sina uppfattningar om pedagogiken som vetenskap. Jag har ögnat även detta och kunnat fastslå att ämnet sannerligen är brett med ett närmast oöverblickbart antal aspekter och ansatser, inåt och utåt. Härtill kan ämnet gratuleras genom att en mängd pedagogiska frågor således fått kvalificerad belysning.

Men jag gör här två reflektioner. Den ena att mångfalden av synsätt sällan möts i konvergerande eller explicit divergerande ställningstaganden som kunde ge upphov till fruktbart meningsutbyte. Den andra att trots omfattande beskrivningar av pedagogikens många möjligheter och företräden ges ytterst få bidrag till tolkningar av ämnets begränsade uppskattning i offentligheten.

\section{SVENSK PEDAGOGIK I DISCIPLINÄRT PERSPEKTIV}

När pedagogikämnet och -forskningen under lång tid haft låg status $\mathrm{i}$ samhällsdebatten följer förstås ett antal frågor om orsaker och konsekvenser. Orsakerna är säkert många och svårfångade, både interna och externa; personliga om ansvar och engagemang, ämnesmässiga om specialintressen och aktualiteter, risk att "oönskade" ställningstaganden möts av smutskastning och trakasserier, välkända svårigheter att få in artiklar och bemötanden i dagspress och nyhetsmedia med mera.

Men sökarljuset måste även riktas inåt, och enligt mitt förmenande särskilt mot frågor om pedagogikens inomvetenskapliga autonomi och akademiska ansvarstagande kring extra-vetenskaplig påverkan, i synnerhet hur intellektuella arbetsvillkor alltför ofta tycks kunna underordnas växlande strömningar i vad som med ett svårdefinierat begrepp kan kallas tidsandan.

Den bristande autonomin fick välkända uttryck redan i det flackande beroendet genom 1900-talet av andra discipliner, med svårigheter att finna vägar till genuint pedagogiska tankeramar. Men viktigare var förmodligen den identitetslösa positivism och empirism som länge var dominerande och underbyggde en oreflekterad normativism kring önskemål om effektiva 
tillämpningar. Jag tror att modernitetens pedagoger alltför ofta gått vilse i förenklad vetenskapstro och politisk heteronomi.

Positivismens senare antites i form av olika slags "tolkism" på likaså teoretiskt underbearbetade grunder må ha följt en tidsanda av tilltagande individualism/subjektivism, men bidrog därmed föga till mer allmängiltig disciplinär kunskap. Med organisatoriska avknoppningar och prefixpedagogiker, liksom nya institutionsstrukturer och -benämningar, kom redan vacklande ämnesgränser att ytterligare försvagas. Utifrån besett finns numera risk att den spridda pedagogikforskningen uppfattas ha föga mer gemensamt än namnet, om ens det under utbildningsvetenskapen hägn.

Traditionella grunder för disciplinär identitetsbildning tycks i långa stycken ha raserats, delvis med effektivt bistånd från statliga reformer. En illustrativ bild ges av hur "installationsföreläsningar" av nya professorer tycks kunna tillgå numera. Jag har tidigare uppfattat som närmast självklart att sådana avses ge en slags bruksanvisning till just disciplinen som samlad kunskapskälla samt lika viktigt en personligt hållen programförklaring därtill. Detta tycks ha förändrats, ibland så att den nyblivna professorn blir intervjuad av ett par kollegor vid institutionen eller berättar om tidigare uppgifter inom lärosätet. Möjligen har detta att göra med den starka tillväxten av professorer med fortsatt tjänstgöring hemmavid, eller att man kanske inte har titeln "i pedagogik" utan i "näraliggande ämnen" eller specifikt forskningsfält, vad vet jag. Men jag tror inte sådant direkt prioriterar just det disciplinära intresset.

Om bakgrunden till bristande intern debatt är svårfångad är en del av följderna desto mer uppenbara. I grunden handlar det som jag ser det om kvalitet $\mathrm{i}$ termer av vetenskaplig kompetens och gemensamt ansvarstagande för ämnets kunskapsbildning. Riskerna är annars att ämnet tappar ytterligare $i$ anseende och inflytande, att (lärar-)studenter får svårare att uppskatta och intressera sig för ämnet, att enskilda arbeten bedöms utifrån organisatorisk status och oreflekterad prestige snarare än på intellektuella grunder. Och utan intern debatt kring kontroversiella ställningstaganden kan man knappast förvänta sig att enskilda forskare ska kunna, vilja eller våga ta steget ut $i$ offentligheten som representanter för ämnet. Vi har ju vid enstaka tillfällen sett hur detta drabbat både personlig integritet och ämnets rykte.

Men största nackdelen tror jag är att forskningen på olika fält inte kan ta tillvara de fördelar som disciplinär kunskapsbildning kan ge. Kanske är jag illa insatt i den senare utvecklingen inom svensk pedagogik, men mitt intryck är att mycket konstruktivt disciplinärt arbete kvarstår som en förhoppning bland en del engagerade. I vilken mån tidigare betydelsefulla ansatser som fenomenografi och läroplansanalys drivits av disciplinära intressen kan jag inte bedöma. Fortfarande kan empiriska studier presenteras utan skönjbar bäring på någon slags disciplinär problematik eller bärkraftig förklaringsmodell som kan övertyga externa skeptiker som söker mer principiell evidens. Om inte annat kunde disciplinanknytning ses som en högst rimlig ingång till 
doktorsavhandlingarnas "Problemställning", "Slutsatser" och "Fortsatt forskning".

Självfallet - självfallet - måste en mängd olika ansatser, teorier och metodologier finnas i forskningen, möjligen ju fler desto bättre. Lika självklart är att forskare ska kunna fördjupa sig i problemområden där det personliga engagemanget finns. Men kanske behövs i avancerad kunskapsbildning någon slags vidare övertygelse om vad det hela handlar om, vad saken $i$ stort gäller, och hur de egna bidragen kan stödja och få stöd av en dynamisk helhet av samlad progression. Ett överblickbart antal konkurrerande synsätt kunde då bidra till viss vetenskaplig objektivitet $i$ närmandet till viktiga grundfenomen via argumenterad konsensus inom en kvalificerad kommunikationsgemenskap.

Eller är kanske pedagogikämnet alltför mångfasetterat, alltför "mångvetenskapligt", alltför svåröverblickbart eller alltför något annat för att kunna identifieras med samlad tankesystematik? Vore en disciplinär hållning en alltför stor inskränkning av forskningens öppna horisonter, den enskilde forskarens frihet att göra som hen finner lämpligt eller något annat som strider mot vetenskapliga ideal?

För egen del skulle jag tro att ett större problem är den tystnadens skenbara harmoni, som yttrar sig i räddhågsen rörelse mot det alltid förväntade eller tillräckligt acceptabla. Den som oroar sig för att disciplinutveckling i aktuell mening skulle medföra en olycklig ensidighet kan därför begrunda den diffust kvasiparadigmatiska samsyn som tidvis varit rådande på mer starflocksliknande grund.

Fast kanske är det så att jag som numera utomstående betraktare fattat fullständigt fel och att pedagogiken som forskningsdisciplin är vid utmärkt vigör och livaktigt verksam? Men då vore väl även aspekter av detta värda fördjupande inlägg i denna tidskrift? Och kanske också ett och annat välgrundat och välbehövligt inlägg om pedagogiska hjärtefrågor i samhällsdebatten?

\section{MEN VADÅ DISCIPLIN?}

Den kanske viktigaste frågan för debatt om disciplinär identitet är väl vad detta överhuvudtaget ska vara bra för. Vad är poängen liksom? Är det inte bara tröttsamt efter alla förnumstigheter som sagts genom decennierna? Nog är det väl viktigare att ämnet har stor bredd med olika möjligheter för enskilda forskare? På vilket sätt skulle det ha betydelse om forskningen är disciplinärt pedagogisk, eller ens kallas "pedagogisk", om den bedrivs enligt vedertagen vetenskaplighet?

Så kan man kanske se på saken, men då bör man också kunna ge goda svar på frågor som dessa:

Vilken karaktär har vetenskapliga fenomen och fakta inom pedagogiken? Hur knyter olika metodologier till skilda föreställningar om kunskap, lärande 
och bildning? Vilka kännetecken har pedagogiska teorier och förklaringar? Vad innebär generalisering i pedagogikforskningen, och behövs sådant? Kan pedagogisk forskning vara replikerbar och i så fall hur? Bör pedagogik räknas som samhällsvetenskap eller humaniora?

Vetenskapliga discipliner brukar kunna hänvisa till ämnets klassiker och hur dessa just därför fortsätter att inspirera dagens forskare. Exempelvis har sociologer ofta ett levande förhållande till sin klassiska trojka Marx - Weber - Durkheim med deras olika uttryck för teoretisk fördjupning och tydlig värderingsrelevans kring disciplinens principiella frågor om samhälleliga integrations- och differentieringsprocesser. Forskning med olika ansatser har kunnat arbeta vidare med att sammanföra resultat till mer konkret kunskap om hur människor i olika roller, institutioner och normsystem samordnar eller drar isär sina samhällen.

Var finns pedagogikens motsvarigheter? Sokrates - Platon - Aristoteles? Comenius - Rousseau - Herbart? - von Humboldt - Durkheim - Dewey? Steiner - Montessori - Freire? Wollstonecraft - Key - Myrdal? Thorndike Pavlov - Skinner? Piaget - Vygotsky - Bandura? Mångfald och valfrihet, javisst, outsinliga källor till bildande berättelser och riskfria riposter. Men var finns den samlade disciplinära problematik, som dagens pedagogiska forskning på något systematiskt sätt kan förhålla sig till? Svar som "tre U", "lärande" eller "praktiknära forskning" är uppenbart otillräckliga.

Det tycks mig som om klassikernas ofta fina filosofier haft svårt att finna vägar till fruktbar ämnesteori på forskningsmässiga grunder. De komplexa helheter som kännetecknar pedagogiska fenomen med avseende på vad som brukar kallas kunskapssyn, människosyn och samhällssyn har reducerats till abstrakta enskildheter utan den nödvändiga begreppsintegration som kan göra rättvisa åt just pedagogikens särart som disciplin.

Uppgiften är ju då inte bara att redovisa resultat från enskilda studier utan att samtidigt bidra till successivt allt mer intresseväckande observationer, givande tolkningar och teorigrundade förklaringar av kritiska sammanhang med vidgad pedagogisk giltighet, också för att kunna föreslå välunderbyggda, evidensbaserade om man så vill, praktiska handlingsinriktningar utifrån disciplinens sakligt argumenterade värdeorientering. Jag är övertygad om att detta också skulle kunna tillföra enskilda projekt väsentliga mervärden, inåt men också utåt.

För saken har ju också viktiga tillämpningsaspekter, exempelvis i skolan. Under lång tid har politiserat prat om "fakta" dominerat delar av debatten. Välmotiverad oro för svaga faktakunskaper och faktaresistens borde då kanske ställas mot oreflekterad oförmåga, eller ovilja, att inse att centrala pedagogiska problem är mer eller mindre starkt kopplade till bistoriskt villkorade sambälleliga fakta. I dilettantisk klagan över exempelvis pedagogisk "relativism" och "konstruktivism" har forskningen trivialiserats utan att möta kvalificerade tillrättalägganden. 
En annan sida av detta är att med selektiva empiriska fakta som retoriskt fokus kan skolforskning och -debatt bedrivas av forskare från i stort sett vilken disciplin som helst. Metodreglerna för empiriska faktastudier kan anses lika för alla, och ofta tycks det tämligen likgiltigt varifrån den "utbildningsvetenskapliga" informationen kommer. Jag anser att bakom den pseudo-konkreta faktafixeringen ligger en speciell kunskapssyn, som även historiskt ofta lyckats dölja underliggande ideologiska ambitioner.

Ingen meningsfull forskning kan bedrivas utan empiriskt stöd, och forskning kan vara kritiskt reflekterad utan att vara disciplinär. Men jag tror disciplinambitionen behöver förstärkas också för att kunna bemöta vinklade skoldebatter med samlade principiella ställningstaganden utifrån långsiktigt bärande fakta.

Av olika skäl är det inte helt enkelt att klargöra de abstrakta tankelinjer som måste avgränsa en pedagogisk disciplin. Vad innebär egentligen en disciplinär ansats? Mitt intryck är att det kan vara svårt att få till ett konstruktivt språkbruk redan kring själva den praktiska innebörden av disciplinbegreppet, förutom den kamerala om forskningens inordning i olika administrativa strukturer; ämnesinstitutioner, resurser, professurer, tidskrifter och liknande.

Under rubriken Pedagogikens fält och disciplinära struktur och i förhoppning om fortsatt debatt dristade jag mig för snart två decennier sedan att $\mathrm{i}$ denna tidskrift föreslå en explicit begreppsdefinition med ungefär följande lydelse: En vetenskaplig disciplin är en organiserad kunskapsbildning i vilken en viss principiell problematik kommer till uttryck och blir föremål för fortsatt forskning och teoribildning ( $\mathrm{Nr} 4,2003$, s. 247).

Jag menade att en etablerad vetenskaplig disciplin, vilket pedagogiken kunde förmodas vara efter ett sekel som universitetsämne, kännetecknas av någon slags sammanhållen identitet där mångfalden av empiriska studier på olika fält sammanfattats i teoretiska modeller med övertygande giltighet inom aktuellt territorium. Inte minst väsentligt är ju detta med teoribildning med ambitionen att förstå och förklara fokuserade fenomen och sammanhang på olika fält. Vidare borde en praktiskt inriktad disciplin, som pedagogik, också kunna hävda en stabil värdeorientering för konkret handlande på sådan disciplinär grund. Detta är ju något helt annat än den normativism som tror sig kunna föreskriva önskvärda insatser rakt av utifrån tillfälligt givna empiriska - kvantitativa eller kvalitativa - fakta.

Underförstått i mitt definitionsförslag är att dynamisk utveckling med nödvändighet i väsentliga delar är en kollektiv process. Vi tillförs hela tiden intryck av främst naturvetenskap som den enskilde forskarens prestigefulla erövringar och det individuella tänkandets överlägsna kraft - vide Nobelfestivalen. Och naturligtvis måste enskilda forskare - i konkurrens - ge viktiga bidrag utifrån egna observationer, tolkningar, teorier och fördjupat tänkande. Ingen disciplin kan utvecklas utan olika personers originella problematiseringar och kreativa lösningar. Men till syvende och sist avser en 
vetenskaplig disciplin en gemensam agens eller som jag vill formulera det, en samlad orientering mot ämnets kärnfrågor.

Väl att märka, det kollektivt eller om så föredras kollegialt fruktbara bör då givetvis ha en saklig inriktning just mot ämnet snarare än mot de former av inskränkningar av kunskapsbildningens sociala organisering som i omogna discipliner sägs kunna yttra sig $i$ allt från balkanisering utifrån inflytelserika kotterier ända ner till mer patetiska uttryck som akademiskt taktiserande urval till rapporternas referenslistor.

Så här långt kommen i min kritik förstår jag att läsare kan önska mer av konstruktiva förslag. I det följande ska jag därför försöka klargöra tydligare hur jag menar med hjälp av några konkretiserande exempel hämtade ur egen fatabur.

\section{EXEMPEL 1: DISCIPLINÄR BILDNING SOM PRINCIPIELL PROBLEMATIK}

Således först grundfrågan; vad handlar egentligen pedagogiken om som vetenskaplig disciplin? I ett tentativt förslag har jag arbetat mig fram till det vid första anblicken enkla påståendet att disciplinens principiella intresse (teori) gäller pedagogisk praktik. Till synes simpelt nog, men snart mer komplicerat. Det leder knappast vidare att sedan mena att vi då har att göra med våra "3U" eller att summera upp ett antal pedagogiska praktikområden. Att forskningen med fördel kan vara "praktiknära" innebär inte heller att en viss etablerad innebörd av praktiken $i$ fråga kan tas för given, utan $i$ stället behövs en explicit avgränsning av vad pedagogisk praktik är, som sådan.

Att då påstå att vad pedagogisk praktik "är" beror på hur man ser den, kan ju verka som den värsta sortens "postmodernism" som drivande skoldebattörer älskar att hata. Fast nu är detta inte en fråga om skolretorikens "faktarelativism" utan om en mångdimensionell tankekonstruktion. Medan forskningsfält är konkret beskrivbara, och kan studeras som fakta, kan en disciplins avgränsning från andra bara ske genom diskursiva överenskommelser med till en början mycket abstrakt karaktär.

Jag har försökt formulera en ansats med lite växlande ordval, men en variant är att pedagogikens principiella problematik avser de praktiska verksambeter inom vilka människor förändrar sina sociala kunskapsrelationer. Talande termer $\mathrm{i}$ en sådan formulering kan sedan bli föremål för begreppsliga konkretiseringar med avseende på relationer mellan individ och samhälle, påverkan och samförstånd, kunskap och kultur, styrning och bildning, handlande och struktur, empiriskt och normativt, effektivitet och legitimitet, tid och plats och andra bärande kategorier.

Detta är alltså ett sätt att se på saken - en klassisk triad av individ, samhälle och kultur om man så vill - och det är då detta som då ska operationaliseras, studeras empiriskt, teoretiseras och allt djupare analyseras ur olika perspektiv och i olika specifika miljöer. I varje pedagogisk praktik kan den integrativa 
treenigheten studeras som uttryck för hur kulturellt grundad kunskaps- och meningsbildning äger rum mellan människor i social interaktion och kommunikation i konkreta historiska och samhälleliga kontexter.

Hur substantiella innehåll ska avgränsas beror på karaktären av olika forskningsfält och metodologiska preferenser. Olika utfall av förändringar, företrädesvis som lärande, kan då aktualiseras; för undervisning i skolan, (kunskapens dimensioner?), interaktion mellan barn och föräldrar (tillit och förtroende?), hälsoinriktad handledning (professionellt bemötande?), studiecirklar bland pensionärer (mening i livet?), forskarutbildning i pedagogik (disciplinär bildning?), pedagogisk debatt (argumentativ övertygelse?).

Bara fantasi och forskningsintresse sätter gränser för de otaliga pedagogiska fält där människor i samspel utvecklar kunskap och delar kulturell mening i och om tillvaron. Min ansats, att utgå från teoretiskt avgränsade former av samhälleligt grundade interaktions- och kommunikationsmönster mellan människor i deras praktiska bildningsverksamhet, är då givetvis bara en variant. Det väsentliga menar jag är att en genomarbetad förståelseram kan relateras till praktiska frågor, så att teori blir ett verktyg för konkret tänkande och inte förblir en mångordig överbyggnad av mer eller mindre anknytande begrepp för utomstående att fastna i.

Vidare anser jag att meningsfull argumentation om ämnets disciplinära ansvar måste inbegripa genomarbetade ställningstaganden till externa beroenden. En praktisk relevant samhällsvetenskap måste rimligen kunna tolka sin egen belägenhet själureflexivt $i$ nuet för att kunna förhålla sig till hur dess roll i samhälle och kultur kan försvaras och fördjupas. Autonomi är då inte en enkel fråga om att åtnjuta si eller så mycket politiskt sanktionerad akademisk frihet, utan gäller hur själva relationen till pågående samhällsutveckling gestaltas i ämnets interna självförståelse. Även detta tror jag vore en viktig ingång till debatt inom ämnet.

\section{EXEMPEL 2: ATT NEGERA SKOLDEBATTENS NEGATIONER AV PEDAGOGIK}

Det kunde likaså vara angeläget att se pedagogikforskningens utsatta ställning i samhällsdebatten $i$ ljuset av den aktuella tidsandans förskjutningar. Traditionell heteronomi med delvis ofrånkomlig anpassning till extern finansiering och önskan om praktisk tillämpning har hängt kvar för att nu i en annan konjunktur vändas mot ämnet. Pedagogikforskningens långvariga normativistiska framtoning som do-gooder i förvaltningspolitiken tycks numera straffa sig i rollen som scapegoat i den offentliga debatten.

Låt mig här anknyta till en essä i denna tidskrift förra året där jag skissade på en förklaring till påträngande inslag i en mångårig skoldebatt och indirekt synen på pedagogikforskningen $(\mathrm{Nr} 1,2020)$. Jag hävdade att en tolkning av 
debattens grundkaraktär kan sökas i den nyliberala privatismens hårda grepp om tidsandan, definitivt och fortsatt inte minst i Sverige. I linje med detta går det att peka på hur forskningen likaså drabbats av den negativa funktionalitet som kännetecknar tidens starka aktiva motstånd mot allt som andas kollektiv solidaritet och gemensamt ansvarstagande på marknivå.

Som typexempel i skoldebatten har pejorativa projektioner av pedagogikforskningen presenterats i banaliserande skenbilder av exempelvis "postmodernism" och "konstruktivism". Helt vid sidan om saklig kritik har detta påståtts yttra sig som oreflekterad relativism och obelagda påhitt, med latent påföljd att de pedagogiska fenomenens kritiska beroende av samhällelig kontextualisering och sociokulturella villkor för lärande kunnat döljas, bortförklaras och motarbetas. Som i en camera obscura har bilder spridits där bedagade ideal om positivistisk metod och invarianta fakta utpekat pedagogikens brister genom vad den inte är som "vetenskap", inte anses kunna bidra med och inte tillgodoser i praktiska sammanhang.

Det retoriska sökarljuset har å ena sidan riktats mot enskilda forskare, varvid någon faktiskt fann det lämpligt att bekräfta forskningens svagheter genom att offentligen be om ursäkt. $\AA$ andra sidan har pedagogikforskningen som helhet gång på gång skopats ut som irrelevant eller rent av destruktiv för skolans utveckling. Detta kan man som pedagog tycka är orättvist, men den faktiska konsekvensen har blivit att ämnet som kollegial kunskapsbas och disciplinär agens $\mathrm{i}$ hög grad har utrangerats från debatten, detta som en klar framgång för aktuella ideologiska bemödanden.

Jag föreställer mig att" "i den bästa av världar" skulle ett effektivt bemötande av osaklig kritik kunnat ske $i$ ett genomarbetat och samlat resonemang från ett antal ämnesföreträdare i auktoritativa klargöranden av hur den vinklade kritiken faller platt mot bakgrund av ämnets disciplinära kunskapsbas. Jag vill gärna tro att detta trots allt hade kunnat få ett visst genomslag i debatten.

Men sådana bidrag uteblir. I stället tvingas vi åse, mot en fond av allt mer svårbemästrad problematik i skola och lärarutbildning, hur lättköpta skenbilder tillåts exkludera eller underminera pedagogiken som åtminstone $\mathrm{i}$ princip hävdad kunskapsinstans. Att göra ner pedagogikforskning har blivit en riskfri angelägenhet utan besvärande mothugg för den så motiverade.

Otrevligt förvisso, men samtidigt skulle just denna projektion av ett pedagogiskt hot mot tidens ideologiska särintressen med fördel kunna bilda ingång till verkningsfull analys av hur en fördjupad disciplinambition kan och kanske måste utformas för att få tyngd även i debatten. I den mån pedagogikens fenomen behöver kontextualiseras samhälleligt, gäller detsamma för den kritiska granskningen av hur forskningen som sådan framställs externt.

En väg till detta kan vara att inslag i den aktuella debatten förstås, empiriskt och värderelaterat, utifrån tidsandans förskjutningar av pedagogikens mest centrala disciplinära begrepp och hur dessa får sina negativt funktionella innebörder, med andra ord att vända på steken och tolka vrångbilderna 
kritiskt. När exempelvis kunskap och lärande, mening och kommunikation, ställs fram som ytliga fakta- och informationsbanaliteter måste rimligen disciplinära motargument kunna omfatta och utmana detta. I sådan dialektik kunde kanske en tankelinje bli att kunskapsgrundade förändringar i människors sociala och kulturella relationer bara kan få långsiktig innebörd i konkreta miljöer av gemensam bildning...

\section{EXEMPEL 3: DISCIPLINÄR BILDNING I FORSKARUTBILDNING}

Jag har pekat på några omständigheter och förändringar under senare decennier som jag anser förhindrat eller försvårat disciplinär utveckling. En del kan anse dessa förändringar önskvärda och lyckade. Men för andra blir väl frågan närmast om slaget är förlorat och att tidigare engagemang för ämnet får riktas åt annat håll. Eller återstår trots allt något område eller några insatser som kunde stärka de disciplinära utsikterna?

Det har länge föresvävat mig att en potential värd betydligt större uppmärksamhet utgörs av ämnets forskarutbildning. Kanske har vi här rent av den enda realistiska arenan för egentlig disciplinär utveckling? Om intern autonomi och framåtblickande tänkande ska visa sig någonstans $\mathrm{i}$ form av kritisk självreflektion över ämnet så borde det väl vara i dess tradering och vidareutveckling just i utbildningen av framtida forskare?

Jag är också rätt säker på att forskarutbildningen för många liksom mig själv står fram som en starkt formativ period för både synen på ämnet och de ibland särpräglade diskursiva praktiker och umgängesformer som kan känneteckna akademiskt liv.

I detta avslutande exempel vill jag därför försöka stimulera till debatt om denna kanske avgörande fråga om i vilken mån och mening forskarutbildning i själva verket kan betraktas som en disciplins främsta praktiska uttryck, empiriskt och normativt. För att bearbeta detta tema kunde behövas stabil grund i empiriska studier och gärna ett antal doktorsavhandlingar, men för att göra det hanterligt här ska jag hämta exempel från egna erfarenheter, dels som doktorand och dels som handledare. Att dessa exempel är utsträckta över ansenlig tid och olika miljöer tror jag kan bidra till att illustrera just den samhälleliga och institutionella kontextens betydelse.

Jag tar utgångspunkt $i$ vad som kan utmärka disciplinärt lärande $i$ forskarutbildning genom att återvända till min disciplindefinition ovan, med viss modifiering:

En forskarutbildning är en organiserad kunskapsbildning $i$ vilken viss principiell problematik. kommer till uttryck och blir föremäl för fortsatt utbildning och forskning.

Om den språkliga horrören ursäktas kan man tala om en "disciplindidaktik" där den principiella problematiken utgör det substantiella innehåll som ska omsättas i adekvat organisering av kunskapsbildningen, såväl i själva utbildningen som i doktorandernas avhandlingsarbeten. Och här vill 
jag apostrofera att organisationen inte enbart gäller kurser, seminarier och handledning om det "kognitiva" innehållet, utan också sociala strukturer i vid mening och de sociokulturella relationerna mellan deltagarna. En viktig sida av detta är att medan disciplinär autonomi kan kräva granskning avseende breda kontextuella villkor, behöver en forskarutbildnings vetenskapliga kvalitet i särskilt hög grad beaktas i termer av villkoren för intellektuell bildning.

Min egen forskarutbildning aktualiserades när jag under sent 1970-tal tjänstgjort en tid som forskningsassistent vid Lärarhögskolan i Malmö/LU i ett stort projekt om pedagogiken i lärarutbildningen. Min uppgift gällde en omfattande enkätundersökning bland utbildningsansvariga kring hur olika aspekter av lärarbefattningen och -utbildningen värderades. Efter omfattande behandling i Den Stora Datamaskinen vid Lunds Datacentral kunde jag ur många kilon "papperslakan" med myriader av siffror extrahera några väsentliga informationer. Med faktoranalyser kunde en struktur över lärarbefattningen beskrivas, och med variansanalyser blev sålunda etablerade "funktioner" för lärare bedömda utifrån betydelse i yrke och utbildning.

Efter att materialet vridits och vänts i en serie publikationer ansågs jag kvalificerad för forskarutbildning med tillräckligt material för en avhandling. Dock hade en sen komplikation tillstött genom att jag hade tagit mig för att granska hur värderingarna av de olika befattningsfunktionerna $i$ läraryrket tycktes variera med hur de beskrevs språkligt. Betydelsen av abstrakta formuleringar hämtade från läroplan tycktes inte alls värderas på samma sätt som när motsvarande innehåll beskrevs $i$ termer av konkreta problemsituationer. Den till synes markanta skillnaden mellan "ideologi och verklighet" blev ett knepigt tolkningsproblem utan lösning inom projektets empiristiska ramar. Det hela blev inte bättre av att jag börjat läsa Horkheimer och Adorno.

Nåväl, efter välvilliga rekommendationer från professor och projektledare lyckades jag erhålla ett stipendium för ett års doktorandstudier vid University of California. Beroende på pedagogikämnets diffusa akademiska status där valde jag en institution för sociologi. Skillnaden i studiemiljö visade sig himmelsvid. Sökande med olika praktiska erfarenheter togs in i grupp, någon från biståndsarbete eller kriminalvård, andra hade kört lastbil eller jobbat $\mathrm{i}$ vården. Erfarenheterna gav upphov till löpande diskussioner om ämnesdisciplinen i relation till respektive specialintressen. Handledarna hämtades från ett kollegium av framstånde forskare, var och en med uttalad teoretisk inriktning och normativ övertygelse, genomgående med tydlig grund i sociologins klassiker. Mycket höga krav ställdes på doktorandernas arbete. För egen del var det en lisa att för en tid delta i en akademisk miljö där det tycktes självklart att utöva vetenskaplig autonomi genom självständigt tänkande och kollegial diskussion. 
Åter i Malmö och en institution med starkt beroende av myndigheter som Skolöverstyrelse och Länsskolnämnd gavs helt andra insikter om forskningens reella villkor. När "metod" utlästes positivistisk data och statistik, och "teori" innebar referens till senaste läroplan och aktuell SOU, blev samhällsvetenskaplig analys med hänvisning till teoretiker som Karl Marx inte direkt någon merit. Frånvaro av handledning blev närmast en fördel i en miljö där vetenskaplig kritik togs som hot mot personliga investeringar $i$ anslag och prestige. Min hållning att pedagogiska fenomen systematiskt villkoras av samhälleliga kontexter avfärdades med att jag sysslade med "sociologi", vilket tvingade fram ängsligt emotsedd granskning från tidens lokala ämnesauktoriteter.

Dessa tidiga direktkontakter med diametralt skilda forsknings- och utbildningsmiljöer blev starkt formativa $\mathrm{i}$ min fortsatta yrkeskarriär. Vetenskaplig självständighet och eget tänkande tycks ibland bara alltför lätt kunna bemötas med repressiv tolerans och akademisk exkommunicering. Min kritiskteoretiska envishet med att pedagogisk teori gäller pedagogisk praktik rimmade också illa med den mekaniska strukturmarxism som då dominerade en liten men högljudd del av svensk pedagogik. Aktivt motstånd och passivt ointresse fick för mig i denna fördigitala tid kompenseras av ett antal tunga internationella recensioner och andra responser. I skeendet läser jag in en del av bakgrunden till svårigheterna för kritisk pedagogik att få fotfäste i Sverige.

I min doktorsavhandling Teaching, science and ideology (Gleerups, 1981) fanns ett självreflexivt grundintresse för hur pedagogikämnets vetenskapliga ansträngningar överflyglats av olika uttryck för politiska underströmmar och hänsynstaganden. Avhandlingen - tydligen den första i landet med explicit fokus på disciplinkritisk reflektion med teoretisk förklaringsambition - gällde undervisningsforskningens framväxt i USA och Sverige under 1900-talet. Jag beskrev de långsiktiga tendenserna som att science of education i USA från sekelskiftet 1900 liksom senare svensk pedagogik uppvisat ett envist beroende av tidsandans ideologiska svängningar och den offentliga förvaltningspolitikens aktuella behov. Det omfattande malmöprojektet blev ett kortfattat men talande exempel på hur sådan heteronomi kan ta sig uttryck också i forskningens metodologiska praktik.

De på flera sätt iögonenfallande parallellerna mellan "utbildningsvetenskapens" etablering i de båda länderna med ett sekel emellan har jag granskat i senare analyser, med slutsatser som att den centrala frågan om kopplingar mellan disciplinär status och vad som $\mathrm{i}$ högtidstalen kallas forskningens frihet $i$ hög grad också har med vetenskapsteoretiska elementa att göra. På olika vis tycks kunskapsbildningens komplexa villkor ibland överflyglas av teknikaliteter där ämnestänkande ersätts av metodisk kompetens, och där tolkningsambition blir till begreppskompilation för att motivera tillrättalagda tillämpningsförslag. 
Senare på Peddan i Lund såg jag en forskarutbildning gå från en extrem till en annan. Efter att obegränsat intag resulterat i över hundratalet inskrivna, huvuddelen utan relevant kontakt med handledare, uppkom på 90-talet en idé om absolut nollintag. Hur något av dessa alternativ över tid skulle kunna återspegla ansvarsfull organisering av institutionens tradering av ämnet lämnar jag åt läsaren att bedöma.

Dessa olika erfarenheter hade jag med mig när jag som professor vid det nya Växjöuniversitetet, senare Linnéuniversitetet, fick den unika möjligheten att bidra till uppbyggnaden av en helt ny forskarutbildning. Som ansvarig ämnesföreträdare engagerade jag mig fullt ut i detta som jag såg som den primära arbetsuppgiften. Hur den vetenskapliga autonomin i dessa ansträngningar kom att utspela sig i praktiken vore värt en egen litania, men här ska jag bara kort notera villkoren $i$ en miljö utan traditionstyngd förankring $\mathrm{i}$ akademiska ideal.

Ambitionen var att utbildningen skulle präglas av disciplinär bildning i kommunikativ gemenskap. I en sorts "community of knowledge" skulle förutsättningar för samordnat arbete byggas genom antagning av doktorander i grupp, uppmuntran till egna studiegrupper, kollegialt lärande med gemensam handledning, uppbyggnad av intern skrivkultur och liknande ansatser. En viktig fråga gällde hur den individuella meriteringen i konkurrens kunde hanteras på explicit kommunikativ grund. Den sålunda organiserande kunskapsbildningen löpte på med stort engagemang och god samsyn under en följd av år, med en serie uppskattade avhandlingar och något oväntat ett mycket positivt utfall i Högskoleverkets nationella ämnesutvärdering.

Efter en produktiv period med den praktiska pedagogikens främsta belöning - att få följa engagerade "disciplar" på deras ofta formidabla bildningsresa - började den disciplinära modellen krackelera. Inte så att den blev utmanad av några uttalade alternativ, vilket annars kunde varit stimulerande. Inte heller $\mathrm{i}$ kritik bland doktoranderna, men administrativt och kollegialt $\mathrm{i}$ en glidande vändning mot nya vindar. Den viktiga gruppvisa antagningen ansågs inte längre ekonomiskt försvarbar, forskarutbildningen skulle ses lite mer som intern kompetensutveckling, ett par nyanställda handledare kände inte igen sig i det kollegiala upplägget, medan det för en annan dynamisk duo spelat ut sin roll i mer aktiv karriärplanering. Det disciplinära anslaget blev allt mindre synonymt med det gemensamma utan verkade snarare som ett hinder för individuella intressen. Allt som allt en blandning av passivt undvikande och aktivt avståndstagande från det tidigare hyllade konceptet $i$ en gradvis förskjutning av verksamhetens bärande element.

Men jag påstår inte att något egentligen gick snett när den kollegiala linjen bröts. Snarare kan man se det hela som en "naturlig" del i det unga växjöuniversitetets successiva erövring av en sorts akademisk normalitet, inbegripet dess ibland särpräglade uttryck för mikropolitiskt spel. Detta 
gynnade de dribblare som nu i en högre division hade fördel av allt bättre försvar på en välbearbetad hemmaplan i sin strävan efter mer taktiskt anpassat spel. Från min egen horisont kunde med viss sublimerad intern ironi konstateras, att forskarutbildningens diskursiva praktik effektivt drevs från kommunikativ rationalitet till strategisk rationalism.

Personliga tolkningar åsido är det autonomiteoretiskt intressant att notera att dessa interna förskjutningar sammanföll med bredare samhälleliga förändringar. Detta hände ju vid en tid då den nyliberala tidsandan med dess New Public Management-tänkande i ledningsfunktioner, bildningsfientliga kunskapssyn och framhävande av privat karriärplanering (med en slags NPMmentalitet också kring forskningsprestationer!) hade fått rejält fotfäste via statliga reformer även inom akademin. Jag menar att givet olika miljöers känslighet för dessa anti-intellektuella strömningar vore det naivt att inte se mycket av det som hände in på 2000-talet och fortsatt i ljuset av denna i delar omvälvande systemförändring. Jag tror nog att en hel del läsare kan vidimera det allmänna mönstret i min miljöbeskrivning ovan.

Jag tror också att många läsare har egna erfarenheter från både doktorandstudier och handledarskap som kunde vara utomordentligt viktiga att dela i konstruktiv ämnesdebatt med inriktning mot klargöranden kring vilka förutsättningar som skulle krävas för att på längre sikt leda pedagogikämnet mot en ljusare framtid.

\section{KRITIK SOM FORSKNINGENS LIVSLUFT}

Kanske är en förhoppning om kvalificerad disciplinär utveckling utan egentlig grund i dagens akademiska verklighet. Eller för den delen dagens samhälleliga verklighet i Sverige där marknadsliberalismens genomslag, trots ett uns av tillnyktring i skoldebatten på senare tid, förblivit särskilt starkt. I själva verket tror jag att det senaste decenniet medfört att vissa samhällstendenser jag noterade i debattinlägget 2011 blivit än mer markanta och ytterligare begränsande för den vetenskapliga autonomin.

Detta borde då rimligen peka än starkare mot att kritisk reflektion måste vara ett avgörande inslag $i$ en utsatt disciplins överlevnadsstrategi - internt $i$ ämnesteoretisk och metodologisk diskussion, externt i välavvägd omsättning av detta i samhällsdebatten. Forskningen måste ha mer att erbjuda än empiriska resultat på snävt avgränsade fält, kanske med metodik som ändå lämnar selektivt fungerande beslutsfattare kalla. Kunskapsöversikter har givetvis sitt värde, men tycks tyvärr ofta stanna vid summeringar utan de teorigenererande metaanalyser som krävs för integrativa slutsatser med övertygande bärighet. Kvalitativa tolkningar utan avancerad principiell kontextualisering blir bara alltför lätt måltavla för intressestyrda påhopp. Elementära vetenskapliga kännetecken som argumenterad reliabilitet, extern 
validitet, generaliserbarhet och giltig evidens måste rimligen ges fastare konturer för att kunna stärka både intern identitet och externt gehör.

Förvisso befarar jag sedan länge att möjligheten att nå ens elementär samsyn om ämnets disciplinära grunder ligger ungefär i nivå med att lösa cirkelns kvadratur, men jag menar att redan en uttalad principiell ambition kunde ha stort värde. Det kunde stimulera en löpande process av kritisk granskning, fördjupad självreflektion, intensifierad diskussion och nya uppslag. Pedagogikämnets sorgliga marginalisering i dagens samhällsdebatt kräver kanske bland mycket annat att ämnets ledande företrädare tar sig i kragen och försöker bidra till tydligare långsiktiga ställningstaganden, i synnerhet inom forskarutbildning och utåtriktad verksamhet. Och jag betvivlar inte alls att en hel del av ämnets många nya professorer, eller för den delen doktorander, har ägnat grundligt tänkande åt den här frågan och bara väntar på bra tillfällen att föra detta till torgs. Kan något forum vara bättre än ämnets ledande tidskrift med dess möjlighet till bred debatt?

Det finns med all säkerhet ett flertal betydelsefulla infallsvinklar och välmotiverade intressen som behöver mötas och bemötas, liksom många bättre genomarbetade tankar och förslag än vad jag lyckats formulera här. Jag är övertygad om att utan konstruktiv intern debatt blir det svårt att bryta pedagogikens ökenvandring $\mathrm{i}$ kommande omvälvande förändringar i samhälle och utbildningssystem. Och mest väsentligt; nog är det svårt att acceptera att grundläggande insikter och normativa övertygelser från pedagogikens långa historia faktiskt kan komma att undandras nya generationer? Så jag slutar som för tio år sedan med en förhoppning om kritiskt meningsutbyte med effektiva mothugg och fortgående fördjupning kring vårt ämnes möjligheter. 